\title{
INOVASI PEMBELAJARAN QUANTUM DAN PENERAPANNYA DI SEKOLAH DASAR
}

\author{
Ersila Devy Rinjani \\ Fakultas Agama Islam Universitas Wahid Hasyim \\ Semarang \\ ersiladevy28@gmail.com
}

\begin{abstract}
Abstrak
Pembelajaran pada kurikulum 2013 telah menerapkan pembelajaran yang berpusat pada peserta didik serta menyenangkan. Proses pembelajaran bertujuan untuk membangun perkembangan peserta didik secara utuh, meliputi aspek keagamaan, aspek sosial, aspek pengetahuan dan aspek keterampilan. Proses pembelajaran juga melibatkan keseluruhan potensi baik potensi psikis maupun potensi fisik. Salah satu model pembelajaran yang dapat mengaktivkan segala aspek adalah model pembelajaran quantum. Inovasi pembelajaran quantum merupakan cara yang digunakan oleh guru dalam mengkomunikasikan materi kepada peserta didik, sehingga proses belajar mengajar berlangsung secara efektif untuk mencapai perkembangan yang optimal. Model pembelajaran quantum menyajikan lingkungan belajar secara terkonsep, meliputi lingkungan mikro, lingkungan makro, maupun lingkungan formal. Model quantum memanfaatkan lingkungan sebagai sumber belajar karena sebagian besar yang ada di alam akan sering ditemui oleh peserta didik. Semakin banyak sumber belajar maka hasil belajar akan bervariasi sehingga pengetahuan yang didapatkan peserta didik pun lebih banyak.
\end{abstract}

Kata Kunci: Inovasi, Quantum, Sekolah Dasar

\begin{abstract}
Learning in K13 already applying student centered learning and fun. The learning process aims to built student development comprehensively, covering religion, social, science and skill aspects. Learning process also involve all potentials both physical and psychology. One of learning model which can be activated in all aspects is quantum learning model. Inovation in quantum learning is a way which can be used by the teachers to deliver teaching material to the students, so the teaching learning process can be optimal. Quantum learning model serve studying environment in good concept, covering micro, macro and formal environment. Quantum model use environment as learning resource because most of thing in nature often will be met by the students. The more learning resources, the more variation in study result and the more knowledge the student will get.
\end{abstract}

Keywords: innovation, quantum, elementary school 


\section{A. PENDAHULUAN}

Pembelajaran merupakan serangkaian kegiatan yang dirancang untuk memungkinkan terjadinya proses belajar pada peserta didik. Pembelajaran juga sebuah proses interaktif antara bahan ajar, guru, dan peserta didik. Selain itu juga model dan metode yang digunakan oleh guru juga sangat menentukan dalam keberhasilan proses pembelajaran. Proses pembelajaran bertujuan untuk membangun perkembangan peserta didik secara utuh, meliputi aspek keagamaan, aspek sosial, aspek pengetahuan dan aspek keterampilan. Pada proses pembelajaran juga melibatkan keseluruhan potensi baik potensi psikis maupun potensi fisik.

Pembelajaran pada kurikulum 2013 sudah menerapkan pembelajaran yang berpusat pada peserta didik dan disampaikan dalam situasi menyenangkan serta penuh kegembiraan. Oleh karena itu guru harus merencanakan model yang sesuai, salah satunya dengan menggunakan model pembelajaran quantum. Hal ini dikarenakan model pembelajaran quantum merupakan bentuk inovasi penggubahan dari bermacam-macam interaksi yang ada disekitar proses belajar. Hasil proses interaksi tersebut yang akan mengubah kemampuan dan bakat alamiah peserta didik menjadi sesuatu yang baru dan bermanfaat baik bagi peserta didik maupun orang lain.

Inovasi pembelajaran quantum merupakan cara yang digunakan oleh guru dalam mengkomunikasikan materi kepada peserta didik sehingga proses belajar mengajar berlangsung secara efektif untuk mencapai perkembangan yang optimal. Model pembelajaran quantum menyajikan lingkungan belajar secara terkonsep, meliputi lingkungan mikro, lingkungan makro, maupun lingkungan formal. Menurut Syaefudin tujuan pokok pembelajaran kuantum yaitu 
meningkatkan partisipasi peserta didik, melalui penggubahan keadaan, meningkatkan motivasi dan minat belajar, meningkatkan daya ingat dan meningkatkan rasa kebersamaan, meningkatkan daya dengar, dan meningkatkan kehalusan perilaku. ${ }^{1}$ Berdasarkan prinsip dan azas landasan pembelajaran kuantum, guru harus mampu mengorkestrasi kesuksesan belajar peserta didik. Dalam pembelajaran kuantum, guru itu tidak semata-mata menerjemahkan kurikulum ke dalam strategi, metode, teknik, dan langkah-langkah pembelajaran, melainkan termasuk juga menterjemahkan kebutuhan nyata peserta didik. Untuk hal itu, dalam pembelajaran kuantum, guru harus memiliki kemampuan untuk mengorkestrasi konteks dan kontens. Konteks berkaitan dengan lingkungan pembelajaran, sedangkan konten berkaitan dengan isi pembelajaran.

\section{B. PEMBAHASAN}

\section{Pengertian Pembelajaran Quantum}

Kata quantum merupakan istilah dari bidang ilmu fisika, mempunyai arti mengubah energi menjadi cahaya. Hal ini mempunyai maksud bahwa pembelajaran quntum merupakan pengubahan bermacam-macam interaksi yang terjadi dalam kegiatan belajar. ${ }^{2}$ Pembelajaran quantum menurut Muflikh merupakan pembelajaran yang digunakan untuk meningkatkan pencapaian hasil belajar yang diinginkan dan untuk pengembangan potensi peserta didik. Proses belajar peserta didik dipengaruhi oleh emosi di dalam dirinya, emosi dapat mempengaruhi baik atau buruk pencapaian

\footnotetext{
${ }^{1}$ Syaefudin Sa'ud, U., Inovasi Pendidikan, Bandung: Alfabeta, 2009, hlm. 130

2 DePorter, B., Readon, M., \& Nourie, S.S., Quantum Teaching (Alih bahasa: Ary Nilandari), Bandung: Mizan, 2001, hlm 16
} 
hasil belajar. ${ }^{3}$ Menurut Roqib pembelajaran quantum merupakan interaksi yang terjadi dalam proses belajar yang mampu mengubah berbagai potensi yang ada dalam diri manusia menjadi pancaran dalam memperoleh hal-hal baru yang dapat ditularkan (ditunjukkan) kepada orang lain seperti: menampilkan hasil diskusi, membaca dan menulis, yang merupakan salah satu bentuk interaksi dalam proses belajar. ${ }^{4}$ Menurut DePorter pembelajaran quantum merupakan penggabungan sugesti dengan teknik percepatan belajar melalui Neuro Linguistic Programming (NLP). Neuro adalah saraf otak, linguistik adalah cara berbahasa, baik verbal maupun nonverbal yang dapat mempengaruhi sistem pikiran, perasaan, dan perilaku. Program NLP sangatlah unik, yaitu melakukan pembangunan mental untuk membuang kebiasaan buruk yang menghasilkan kegagalan, pesimisme, kurang percaya diri, digantikan dengan yang dapat mengoptimalkan semua fungsi otak, mengidentifikasikan hal-hal yang memicu pola berpikir positif. 5

Berdasarkan beberapa pendapat dari berbagai sumber dapat disimpulkan bahwa pembelajaran quantum merupakan proses pengubahan interaksi dalam proses belajar peserta didik untuk mengembangkan potensi yang dimiliki peserta didik. Pada proses ini dimulai dengan pembangunan mental peserta didik secara mendasar melalui NLP, yang dapat mempengaruhi sistem pikiran, perasaan, dan perilaku. Hal ini bertujuan untuk membuang kebiasaan buruk peserta didik seperti pesimis, kurang percaya diri, pemalu, dll.

3 Muflikh Fuadi, A., Pelaksanaan Pembelajaran Quantum Di Sekolah Dasar Muhammadiyah I Magetan. Tesis Pascasarjana UNS: Surakarta, 2009, hlm. 42

${ }^{4}$ Roqib, M., Ilmu Pendidikan Islam, Yogyakarta: LKIS, 2009, hlm. 110

5 DePorter, Quantum Learning: Membiasakan Belajar Nyaman dan Menyenangkan, Bandung: KAIFA, 1999, hlm. 16 
Sehingga diharapkan dalam pembelajaran quantum peserta didik dapat aktif, kreatif dan menyenangkan.

\section{Ciri-Ciri Pembelajaran Quantum}

Menurut DePorter, Reardon, dan Singer Nourie ciri umum pembelajaran quantum sebagai berikut:

a. Pembelajaran berpangkal pada psikologi kognitif;

b. Pembelajaran bersifat humanistis, dan konstruktivis;

c. Pembelajaran memusatkan perhatian pada interaksi yang bermutu dan bermakna ganda;

d. Pembelajaran menekankan pada pemercepatan dengan taraf keberhasilan tinggi, kealamiahan dan kewajaran proses;

e. Pembelajaran memiliki model yang dipadukan dengan konteks dan isi;

f. Pembelajaran memusatkan perhatian pada pembentukan keterampilan dalam proses belajar;

g. Pembelajaran menempatkan nilai dan keyakinan sebagai bagian penting dalam proses pembelajaran bermakna;

h. Pembelajaran mengutamakan keberagaman dan kebebasan; dan

i. Pembelajaran mengintegrasikan totalitas tubuh dan pikiran dalam proses pembelajaran. ${ }^{6}$

Menurut DePorter pembelajaran quantum mempunyai ciri spesifik, antara lain:

a. Learning to know yang artinya belajar untuk mengetahui;

b. Learning to do yang artinya belajar untuk melakukan;

c. Learning to be yang artinya untuk menjadi dirinya sendiri; dan

${ }^{6}$ DePorter, B., Readon, M., \& Nourie, S.S., Quantum Teaching (Alih bahasa: Ary Nilandari), Bandung: Mizan. 2001, hlm.5 
d. Learning to live together yang artinya belajar untuk kebersamaan. ${ }^{7}$

\section{Asas dan Prinsip Pembelajaran Quantum}

Menurut Syaefudin asas pembelajaran quantum ada dua yaitu bawalah dunia mereka ke dunia kita dan antarkanlah dunia kita ke dunia mereka. Makna ini mempunyai maksud bahwa pengajaran menggunakan model quantum tidak hanya menawarkan materi yang diajarkan tetapi juga menciptakan hubungan emosional yang baik dalam kegiatan pembelajaran. Pembelajaran yang demikian disebut juga kegiatan full content yang melibatkan semua aspek kepribadian peserta didik (pikiran, perasaan dan bahasa tubuh) disamping pengetahuan, sikap dan keyakinan sebelumnya juga persepsi masa mendatang. Oleh karena itu pembelajaran quantum berusaha mengubah suasana belajar yang monoton dan membosankan ke dalam suasana belajar yang gembira dengan memadukan potensi fisik, psikis dan emosi peserta didik menjadi kesatuan kekuatan yang menyatu.

Prinsip pembelajaran quantum antara lain:

a. Segalanya berbicara;

b. Segalanya bertujuan;

c. Pengalaman sebelum pemberian nama;

d. Akui setiap usaha; dan

e. Jika layak dipelajari maka layak pula dirayakan. ${ }^{8}$

${ }^{7}$ DePorter, B., Readon, M., \& Nourie, S.S., Quantum Teaching (Alih bahasa: Ary Nilandari), Bandung: Mizan. 2002, hlm.54 127-129

8 Syaefudin Sa'ud, U., Inovasi Pendidikan, Bandung: Alfabeta, 2009, hlm. 
Menurut Iru Prinsip model pembelajaran quantum, meliputi:

a. Terapkan hidup dalam integritas;

b. Ketahuilah kegagalan dapat membawa kesuksesan;

c. Berbicaralah dengan niat baik;

d. Tegaskanlah komitmen;

e. Jadilah pemilik;

f. Tetaplah lentur; dan

g. Pertahankanlah keseimbangan. ${ }^{9}$

\section{Strategi Pembelajaran Quantum}

Menurut DePorter dalam Syaefudin strategi pembelajaran kuantum melalui istilah TANDUR, yaitu:

a.Tumbuhkan, yaitu dengan memberikan apersepsi yang cukup sehingga sejak awal kegiatan peserta didik telah termotivasi untuk belajar dan memahami Apa Manfaatnya Bagiku (AMBAK);

b.Alami, berikan pengalaman nyata kepada setiap peserta didik untuk mencoba;

c. Namai, sediakan kata kunci, konsep, model, rumus, strategi dan metode lainnya;

d.Demonstrasikan, sediakan kesempatan kepada peserta didik untuk menunjukkan kemampuannya;

e.Ulangi, beri kesempatan untuk mengulangi apa yang telah dipelajarinya, sehingga setiap peserta didik merasakan langsung dimana kesulitan akhirnya datang kesuksesan, kami bisa bahwa kami memang bisa; dan

f. Rayakan, dimaksudkan sebagai respon pengakuan yang proporsional. ${ }^{10}$

${ }^{9}$ Iru, La \& La Ode Safiun Arihi., Analisis Penerapan Pendekatan, Metode, Strategi dan Model-Model Pembelajaran, Bantul: Multi Presindo, 2012, hlm.95-96 
Hakikatnya strategi ini dapat diringkas menjadi tiga langkah, yaitu pendahuluan, inti dan penutup. Dimana pendahuluan meliputi tumbuhkan, inti meliputi alami, namai dan demonstrasikan, sedangkan penutup meliputi ulangi dan rayakan.

\section{Model Pembelajaran Quantum}

Tujuan pembelajaran kuantum menurut Meier dalam Muflikh untuk membangunkan kemampuan yang sepenuhnya minat belajar para peserta didik, membuat belajar menjadi menyenangkan dan memuaskan serta memberikan pengaruh pada kebahagiaan, kecerdasan kompetensi, dan keberhasilan dalam belajar.11 Pembelajaran quantum memberdayakan semua yang ada dalam pembelajaran, baik secara konteks (latar pengalaman guru dan peserta didik) dan konten (isi).

Konteks adalah latar pengalaman guru dan peserta didik. Konteks merupakan keakraban komponen dalam pembelajaran yaitu guru, peserta didik, dan kurikulum. Menurut DePorter konteks terbagi menjadi Lingkungan, suasana, landasan, rancangan. Lingkungan adalah komponen pembelajaran itu sendiri yaitu guru, peserta didik, kurikulum, dan kelas serta sekolah. Lingkungan meliputi lingkungan secara fisik dan lingkungan secara sosial. Penataan ruang kelas, dan bagaimana komunikasi antar komponen dalam pembelajaran. Suasana dianalogikan sebagai semangat para konduktor dan pemain musiknya dalam hal ini peserta didik dan guru.

${ }^{10}$ Syaefudin Sa'ud, U., Inovasi Pendidikan, Bandung: Alfabeta, 2009, hlm 129

11 Muflikh Fuadi, A., Pelaksanaan Pembelajaran Quantum Di Sekolah Dasar Muhammadiyah I Magetan. Tesis Pascasarjana UNS: Surakarta, 2009, hlm 27

52 MAGISTRA - Volume 8 Nomor 1 Juni 2017 
Menurut Deporter dalam Syaefudin model pembelajaran quantum meliputi tiga langkah yaitu: 1. Optimalkan minat pada diri; 2. Bertanggung jawab pada diri; dan 3. Hargailah segala tugas yang telah selesai.12 Kegiatan pembelajaran yang baik menurut Prastowo adalah kegiatan pembelajaran yang dapat memanfaatkan semua potensi yang ada baik dari guru, peserta didik, sumber dan media. Hal ini dikarenakan dalam model pembelajaran quantum peserta didik belajar berdasarkan pengalaman, belajar dengan simbol, dan simulasi atau permainan. ${ }^{13}$ Jadi model quantum dalam kegiatan pembelajaran dapat memanfaatkan lingkungan sebagai sumber belajar karena sebagian besar yang ada di alam akan sering ditemui oleh peserta didik. Semakin banyak sumber belajar maka hasil belajar akan bervariasi sehingga pengetahuan yang didapatkan peserta didik pun lebih banyak.

\section{Penerapan Pembelajaran Quantum di Sekolah Dasar}

Kelas/ Semester : : II/ I

Tema $\quad: 2$. Bermain di Lingkunganku

Subtema $\quad: 1$. Bermain di lingkungan rumah

Pembelajaran ke $\quad: 1$

Pola pembelajaran model quantum learning sebagai berikut:

\begin{tabular}{|l|l|}
\hline Langkah Pembelajaran Quantum & Langkah Pembelajaran Guru \\
\hline Tumbuhkan & a. $\begin{array}{l}\text { Guru menyajikan gambar Beni } \\
\text { bermain menyusun rumah }\end{array}$ \\
& $\begin{array}{l}\text { kartu dengan Tiur. } \\
\text { b. Peserta didik mengamati } \\
\text { gambar dan guru menarik } \\
\text { perhatian peserta didik }\end{array}$ \\
\hline
\end{tabular}

130

12 Syaefudin Sa'ud, U., Inovasi Pendidikan, Bandung: Alfabeta, 2009, hlm

13 Prastowo, A., Pengembangan Bahan Ajar Tematik; Panduan Lengkap Aplikatif, Jogjakarta: Diva press, 2013, hlm 97

MAGISTRA - Volume 8 Nomor 1 Juni 2017 


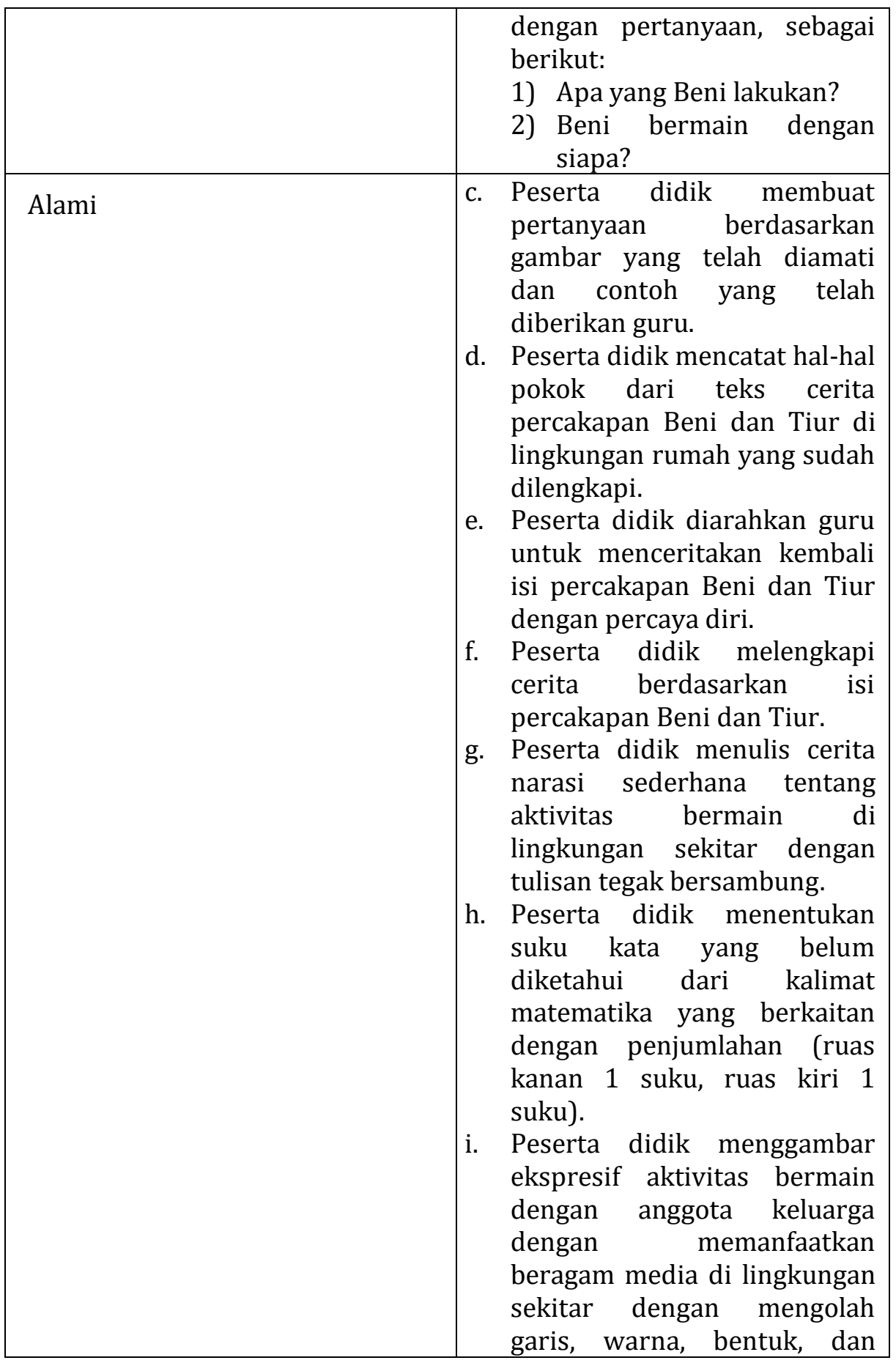




\begin{tabular}{|c|c|c|}
\hline & & tekstur \\
\hline Namai & & $\begin{array}{l}\text { Peserta didik memberi } \\
\text { alasan yang berkaitan } \\
\text { dengan nilai kebenaran } \\
\text { suatu kesamaan. } \\
\text { Mendefinisikan judul dari } \\
\text { gambar ekspresif yang } \\
\text { telah dibuat. }\end{array}$ \\
\hline Demontrasikan & & $\begin{array}{lr}\text { Peserta didik membaca } \\
\text { teks percakapan Beni dan } \\
\text { Tiur. } \\
\text { Peserta didik bertanya } \\
\text { jawab menyebutkan } \\
\text { keberagaman anggota } \\
\text { keluarga berdasarkan isi } \\
\text { percakapan Beni dan Tiur. } \\
\text { Peserta didik menceritakan } \\
\text { kebersamaan dengan } \\
\text { anggota keluarga yang } \\
\text { berbeda jenis kelamin, } \\
\text { kegemaran dan sifat } \\
\text { (karakter) } \\
\text { melengkapi cerita tentang } \\
\text { dirinya sendiri. }\end{array}$ \\
\hline Ulangi & & $\begin{array}{l}\text { Membuat simpulan/ } \\
\text { rangkuman hasil belajar } \\
\text { selama sehari. } \\
\text { Bertanya jawab materi } \\
\text { yang telah dipelajari. }\end{array}$ \\
\hline Rayakan & & $\begin{array}{l}\text { Dengan pemberian reward } \\
\text { atau pujian. }\end{array}$ \\
\hline
\end{tabular}

\section{SIMPULAN}

Pembelajaran quantum merupakan pembelajaran yang digunakan untuk meningkatkan pencapaian hasil belajar yang diinginkan dan untuk pengembangan potensi peserta didik. Proses belajar peserta didik 
dipengaruhi oleh emosi di dalam dirinya, emosi dapat mempengaruhi baik atau buruk pencapaian hasil belajar. Asas pembelajaran quantum ada dua yaitu bawalah dunia mereka ke dunia kita dan antarkanlah dunia kita ke dunia mereka. Makna ini mempunyai maksud bahwa pengajaran menggunakan model quantum tidak hanya menawarkan materi yang diajarkan tetapi juga menciptakan hubungan emosional yang baik dalam kegiatan pembelajaran. Tujuan pembelajaran kuantum untuk membangunkan kemampuan yang sepenuhnya minat belajar para peserta didik, membuat belajar menjadi menyenangkan dan memuaskan serta memberikan pengaruh pada kebahagiaan, kecerdasan kompetensi, dan keberhasilan dalam belajar. 


\section{DAFTAR PUSTAKA}

DePorter, B., Readon, M., \& Nourie, S.S, Quantum Teaching (Alih bahasa: Ary Nilandari). Bandung: Mizan, 2001.

DePorter, B., \& Hernacki, M, Quantum Learning (Terjemahan oleh Alwiyah Abdurrahman). Jakarta: Kaifa, 2002.

— Quantum Learning: Membiasakan Belajar Nyaman dan Menyenangkan, Bandung: Kaifa PT Mizan Pustaka, 2009.

— Quantum Learning: Membiasakan Belajar Nyaman dan Menyenangkan. Bandung: KAIFA, 1999.

Iru, La \& La Ode Safiun Arihi, Analisis Penerapan Pendekatan, Metode, Strategi dan Model-Model Pembelajaran. Bantul: multi presindo, 2012.

Muflikh Fuadi, A, Pelaksanaan Pembelajaran Quantum Di Sekolah Dasar Muhammadiyah I Magetan. Tesis Pascasarjana UNS: Surakarta, 2009.

Prastowo, A, Pengembangan Bahan Ajar Tematik; Panduan Lengkap Aplikatif, Jogjakarta: Diva press, 2013.

Roqib, M, Ilmu Pendidikan Islam, Yogyakarta: LKIS, 2009.

Syaefudin Sa'ud, U, Inovasi Pendidikan. Bandung: Alfabeta, 2009. 